\title{
New species and subspecies of Leucopogon (Epacridaceae) in New South Wales
}

\author{
J.M. Powell and G. Robertson
}

\begin{abstract}
Powell, J.M. and Robertson, G. (National Herbarium of New South Wales, Royal Botanic Gardens, Sydney, NSW, Australia 2000) 1993. New species and subspecies of Leucopogon (Epacridaceae) in New South Wales. Telopea 5(2): 381-397. Two new species are described: Leucopogon cicatricatus J. Powell and L. trichostylus J. Powell, and a new subspecies within Leucopogon fletcheri Maiden \& Betche established: subsp. brevisepalus J. Powell. Notes on the nomenclature, distribution and ecology are given.
\end{abstract}

\section{Introduction}

Leucopogon in the broad sense, the largest genus in the family Epacridaceae, has been the focus of revisionary studies for a number of years and many new taxa are being recognized. Some 31 species and two subspecies of Leucopogon were recorded, and a further four taxa were noted as requiring investigation to establish their identity and status, in the 1981 census of plants in New South Wales (Jacobs \& Pickard 1981). Study of these collections while preparing a treatment for the Flora of New South Wales has led to the recognition of three new taxa.

Leucopogon cicatricatus J. Powell, sp. nov.

Species propria; folia conferta, anguste oblonga, convexa marginibus recurvis, subter valde parallelinervia et ceraceo-glauca; cicatrices foliorum prominentes. Flores conspicui; spicae erectae breves ad apices ramulorum fasciculatae; tubus corollae sepala aequans vel tantum superans; limbus corollae tubum aequans vel eo longior, intus dense albo-barbatus. Drupa coccinea depresso-globosa, 5-9-locularis.

Type: New South WalEs: Northern Tablelands: Wrights Lookout Track, New England National Park, J.M. Powell 2979, 2 Sep 1987 (holo NSW 206010; iso BRI, K).

A slender to erect sparsely branched shrub, sometimes more compact, usually 50-70 $\mathrm{cm}$ high, sometimes up to $120 \mathrm{~cm}$. Stems thin, erect, brown or grey-brown, glabrous, with smooth to somewhat tessellated bark and with prominently raised, crowded leaf scars, giving a scarred appearance; branchlets red-brown, with prominent ridged nodes giving a torulose aspect, scabridulous to hispidulous. Leaves often densely crowded on branchlets (Figure 1a), erect, sub-erect or occasionally horizontally spreading, spiral; lamina narrowly oblong or linear, 9.9-18.5 mm long, 1.4-2.5 mm wide adaxially (lamina length: width ratio = 6-11:1); apex acute, with mucro $0.3-0.8 \mathrm{~mm}$ long; base narrowing; lamina convex adaxially (Figure 1b), glabrous, discolorous, waxy-glaucous and strongly ribbed and furrowed abaxially (Figure 2a, b); margins recurved, entire (Figure 2a); petiole distinct, $0.5-1.5 \mathrm{~mm}$ long, glabrous or hispidulous. Leaves at the start of the growing season (enclosed initially in brown, ovate, tomentose bracts) thin, flat or slightly concave adaxially, with hyaline and ciliolate margins towards the apex. Inflorescences terminal on short shoots or in the uppermost axils of the main branches, the spikes erect, 7-12 mm long, clustered, and just overtopping the leaves (Figure 1a), each with 2-6 flowers plus a bud-like rudiment and up to 4 or 
5 sterile bracts at the base; peduncles woolly. Flowers conspicuous, erect, the corolla white, the buds often pink-tipped. Bracts ovate, 1.1-1.8 $\mathrm{mm}$ long, 1.2-1.9 mm wide, sub-obtuse or obtuse, with a very small callus, striate-veined, puberulent, with ciliolate margins. Bracteoles ovate, 1.8-2.4 mm long, 1.6-2 mm wide, acute or broadly acute, keeled, puberulent to tomentose outside; margins ciliolate to ciliate towards the apex. Sepals often reddish, broadly ovate, $2.7-3.8 \mathrm{~mm}$ long, $1.8-2.5 \mathrm{~mm}$ wide, broadly acute or obtuse with a callus, the midrib inconspicuous, puberulent to tomentose outside and with the margins ciliate. Corolla: tube sub-campanulate, quite fleshy, equal to or just exceeding the sepals (Figure 1c, d), 2.2-2.8 mm long, 1.7-2.1 $\mathrm{mm}$ wide, glabrous outside, pilose at the throat or over the upper half inside; lobes
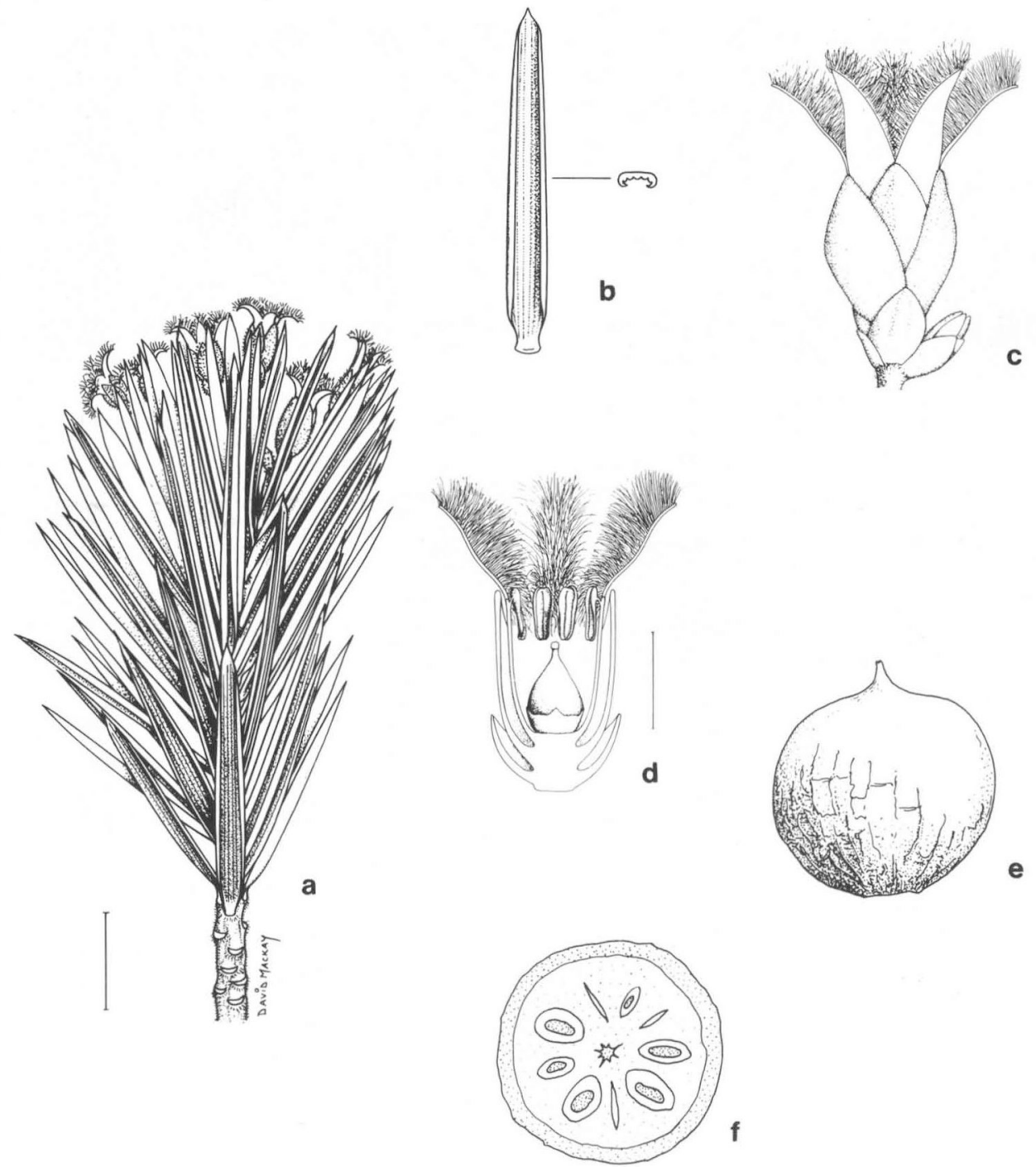

Figure 1. Flowering branch, leaf, flower and fruit structure of Leucopogon cicatricatus J. Powell. a, flowering branch (Powell 1050 \& Armstrong, scale bar $=5 \mathrm{~mm}$ ); b, detail of leaf and transverse section (Powell 1050 \& Armstrong, scale bar = $4 \mathrm{~mm}$ ); c,d, flower and flower section (Burgess H213, scale bar = $2 \mathrm{~mm}$ ); e,f, fruit structure (Binns NSW 248971, scale bar = $2 \mathrm{~mm}$ ). 
triangular, equal to or longer than the tube, 2.5-3.0 $\mathrm{mm}$ long, $0.8-1.1 \mathrm{~mm}$ wide, acute, glabrous outside, woolly inside with ornamented hairs (Figure 2e) that are longer over the upper half. Anthers obvious at the throat, 1.1-1.3 $\mathrm{mm}$ long, with a minute recurved sterile tip; filaments $0.2-0.3 \mathrm{~mm}$ long, attached near the apex of the anther (Figure 2c). Ovary ovoid or almost rhomboidal, $0.8-1.3 \mathrm{~mm}$ high, 1.1-1.4 mm wide, usually slightly ribbed, glabrous, 5-9-locular; style $0.7-1.3 \mathrm{~mm}$ long, cylindrical and papillose near stigma, cone-like below, broadening to ovary (Figure 2f), not exserted from the corolla-tube; stigma minute; nectary annular, $0.4-0.5 \mathrm{~mm}$ high, with irregular upper margin (Figure 2f). Fruit bright red, fleshy, exceeding the sepals, depressedglobose, 3.8-5.3 $\mathrm{mm}$ high, 4-6 $\mathrm{mm}$ wide, flat-topped, smooth or ridged, glabrous, the style-base persistent (Figure 1e, f); woody endocarp strongly ridged.
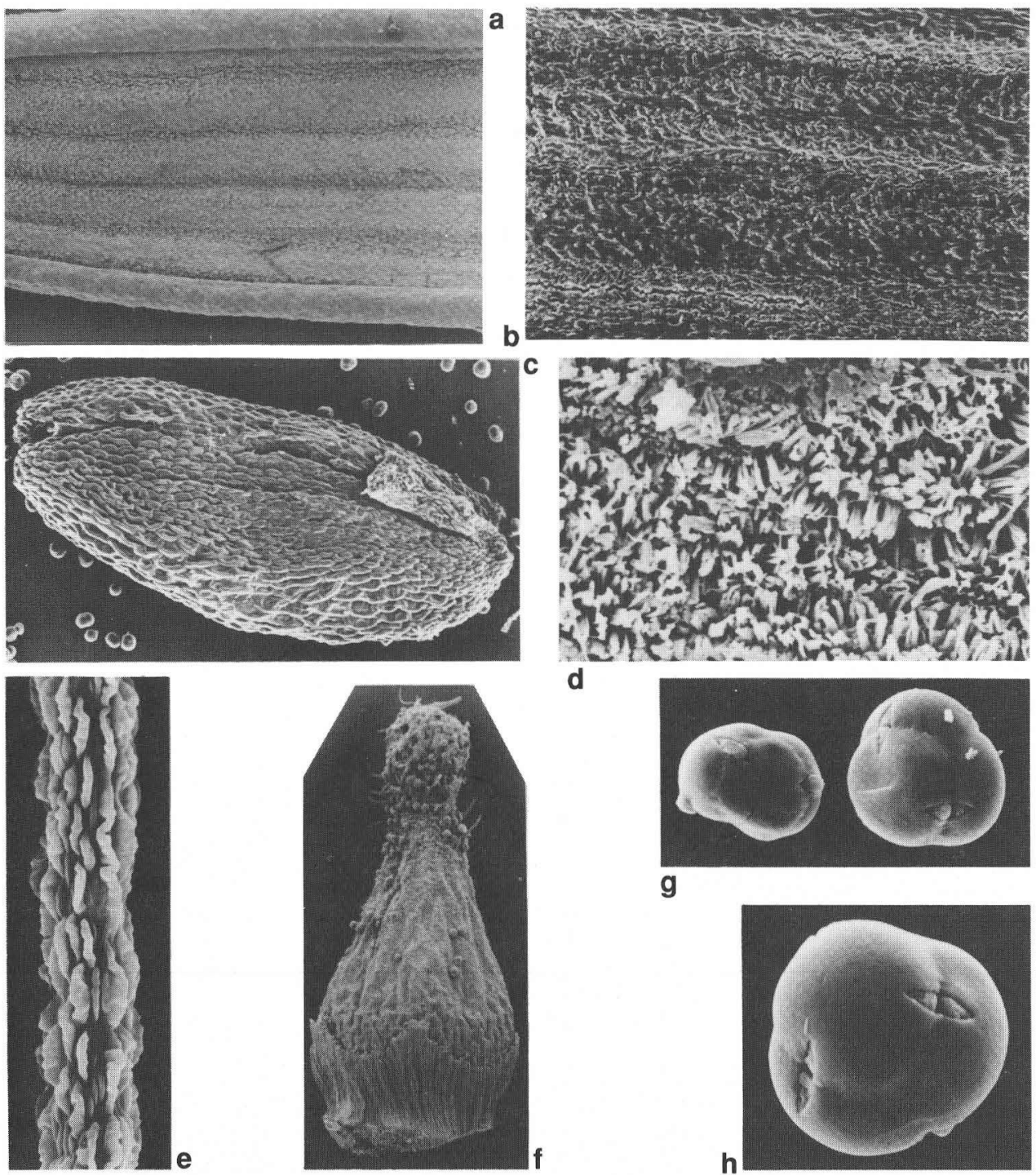

d

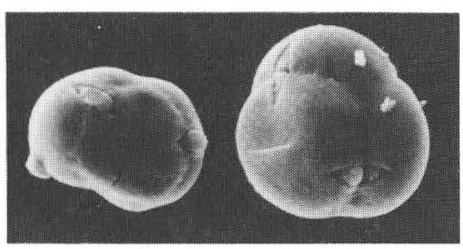

g

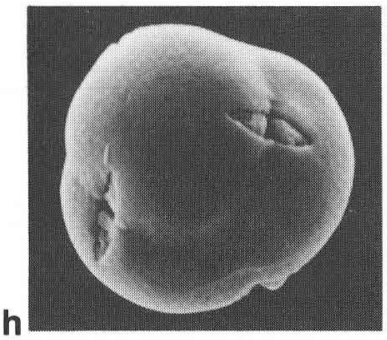

Figure 2. Scanning electron micrographs of L. cicatricatus J. Powell. a, lower leaf surface ( $x$ 22); b, lower leaf surface $(x 44)$; c , anther and filament attachment, from dorsal side $(x 60)$; $d$, lower leaf surface wax (x 1650); e, corolla hair (x 1100); f, gynoecium ( $x 35) ; \mathrm{g}$, pollen tetrads and dyads (x 500); $\mathbf{h}$, detail of tetrad (x 840). 
Derivation of ePITHET: From the Latin cicatricatus, scarred, referring to the prominent leaf scars on the branches.

FLOWERING AND FRUITING PERIOD: Flowers August to November. Fruits are recorded from August to December (mainly September) and also rarely in June suggesting that they mature over the winter.

Habitat: Grows at high altitudes (1000-1600 m) in rock crevices and on exposed windswept plateaus and mountain summits in sparse shrubby vegetation (dominated by Myrtaceae, Epacridaceae and sometimes Allocasuarina) on skeletal sandy soils over granite or other igneous rocks.

Distribution: Known from the North Coast and Northern Tablelands of New South Wales and from Mt Barney in the McPherson Range, Queensland (Figure 3).

Conservation STATUS: Although populations are isolated and usually relatively small, the species is conserved in New England and Cathedral Rock National Parks, in Bulga State Forest and on Mt Barney; a conservation value of 3RC is appropriate following Briggs \& Leigh (1988).

Notes: This species is very distinct from other eastern Australian Leucopogon species; its relations lie more in Western Australia with such taxa as L. atherolepis Stschegl. and L. mollis E. Pritzel. Currently it is placed within Bentham's Section Perojoa, series

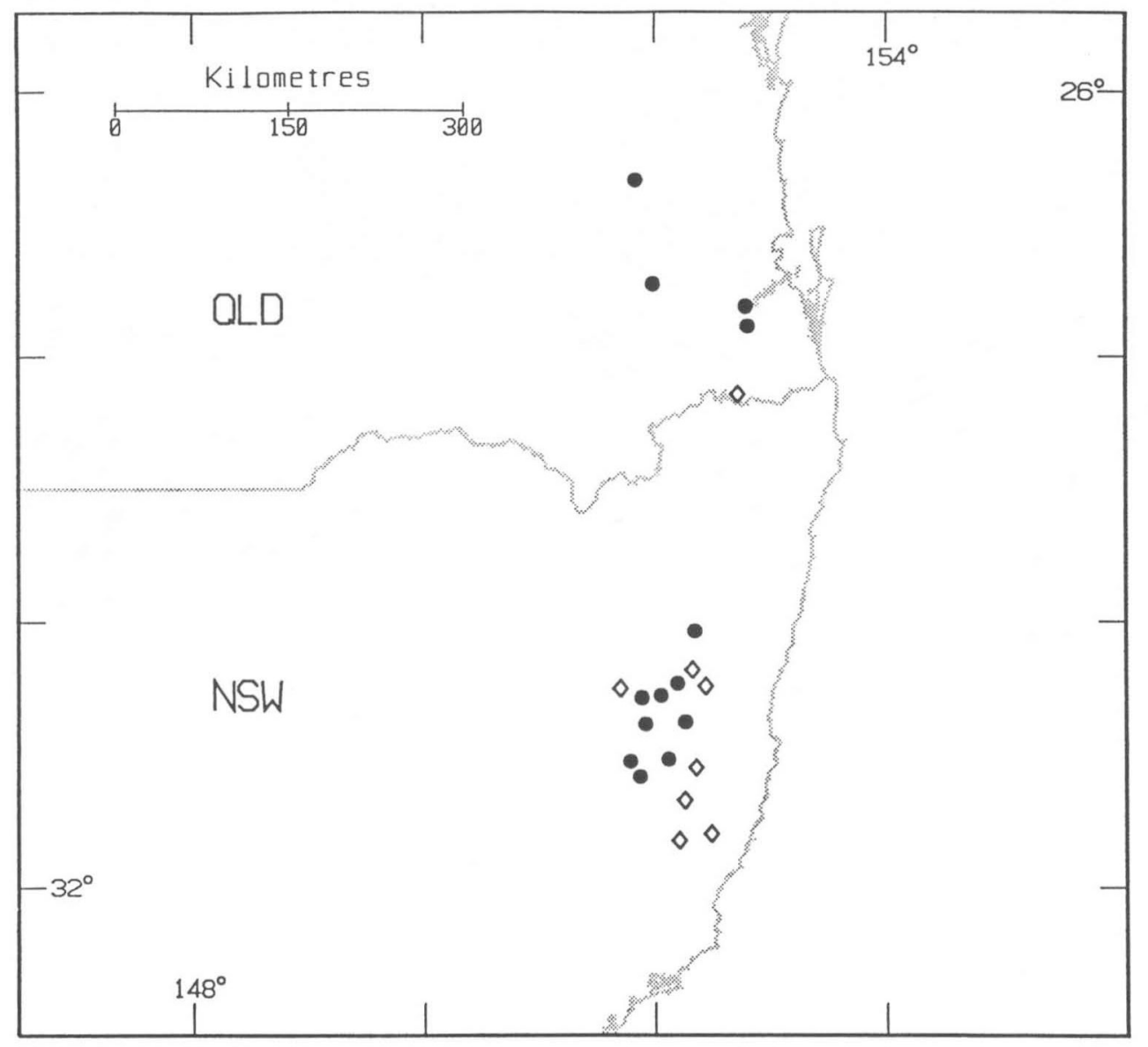

Figure 3. Distribution of L. cicatricatus J. Powell $(\diamond)$ and L. trichostylus J. Powell $(\bullet)$. 
Australes (Bentham 1869) and will remain within Leucopogon in the strict sense when generic changes are formalized (Powell, unpublished work). Although known previously as Leucopogon sp. aff. pedicellatus because of the superficial resemblance of the leaves to that species, it is not closely related to it. L. pedicellatus C. White is being transferred to the genus Lissanthe (Powell, unpublished ms.).

The pollen of L. cicatricatus is in tetrads and modified tetrads (dyads and monads), tricolporate and scabrate (Figure $2 \mathrm{~g}$, h). The corolla hairs are single celled, straight, with sparse linear tubercles (Figure 2e). The ribbed and furrowed leaf undersurface has waxy hairs along the furrows (Figure 2a, b); the wax is mixed ribbon and plate wax (Figure 2d), following the terminology of Mihaich, Crowden \& Powell (unpublished ms.).

Selected specimens examined: New South Wales: North Coast: Bulga State Forest, Rowleys Rock Trig, Burgess H213, 15 Sep 1976 (NSW); Comboyne, Chisholm 442, Jun 1934 (NSW); Comboyne Plateau, Stanton, Aug 1952 (NSW 248967). Northern Tablelands: Carrai State Forest, near Spokes Trail, Binns, 10 Dec 1986 (NSW 248971); Round Mountain, Snowy Range, Burgess, 26 Sep 1972 (NSW 248969); Wrights Lookout track, New England National Park, Powell 2978, 2 Sep 1987; Snowy Mountain Range, 3.5 km NNE of Round Mountain, Telford 10420, 27 Sep 1987 (CBG, NSW, MEL); Wrights Plateau, near Point Lookout, Williams 67, Nov 1958 (NSW); 2 km WSW of Point Lookout, New England National Park, Williams 72-605, 12 Nov 1972 (NE); Cathedral Rock area, c. $79 \mathrm{~km}$ E of Armidale, Wissman, Mar 1972 (NE 24934). QueENSLAND: Moreton: Mt Barney, Constable, 15 Nov 1952 (NSW 24341); Goy \& Smith 4, 5 Sep 1937 (BRI); East Peak summit area, Mt Barney, Powell 1050 \& Armstrong, 26 Sep 1977 (NSW).

\section{Leucopogon trichostylus J. Powell, sp. nov.}

A L. fraseri habitu elatiore, caulibus erectis vel expansis, ramis saepe intertextis, sparsifoliatis, foliis aliquantum grandioribus, apice angustiore, petiolo longiore, inflorescentiis saepe trifloribus, differt.

Type: New South Wales: Northern Tablelands: Blue Mountain Creek, c. 33 km SE of Armidale, J.B. Williams, 12 Oct 1984 (holo NSW 250764; iso NE).

Erect to spreading shrub with many intertwined branches, 60-210 cm high. Stems grey-brown to dark grey, glabrous, with grey stringy bark and leaf scars relatively prominent, crescent-shaped; branchlets light yellow-brown or brown, somewhat ribbed, hispidulous. Leaves often crowded on branchlets, erect to horizontally spreading (Figure 4a), non-imbricate, spiral; lamina elliptic to slightly obovate, or sometimes elliptic-oblong (Figure 4d, e), 7.7-17.2 $\mathrm{mm}$ long, 2-3.7 $\mathrm{mm}$ wide (length: width ratio = 3.1-4.8:1); apex narrowly acute to shortly acuminate, with aristate tip 0.9-1.6 mm long (Figure 5a); base cuneate; lamina thick, flat or slightly concave or convex, shiny and glabrous or scabrous along midline and towards base adaxially, dull, paler and often waxy-scabrous abaxially (Figure 5e, g), with 5-7 central parallel veins and a further 8-9 sub-parallel veins abaxially (Figure 5a); margin minutely denticulate overall (Figure 5c), the teeth often denser towards the leaf apex; petiole poorly developed, often scabrous adaxially, 0.5-1.2 mm long. Leaves at the start of the growing season with hyaline denticulate margins; rapid main stem growth with horizontally spreading to somewhat reflexed leaves, widely spaced, the same size as or slightly larger than those on the branches. Inflorescences erect to spreading, in uppermost axils of the short branchlets, equal to or shorter than the leaves; each spike with up to 3 flowers and a bud-like rudiment, and 1 or 2 sterile bracts together with a pair of acuminate keeled bracts at the base; peduncles pubescent, $0.5-1.5 \mathrm{~mm}$ long. Flowers relatively conspicuous, erect to spreading, white. Bracts sub-orbicular, 0.9-1.6 mm long, 0.9-1.3 $\mathrm{mm}$ wide, sub-obtuse or obtuse with a small apiculum, striate-veined, the midrib thickened only at the apex, glabrous and with minutely fringed margins. Bracteoles sub-orbicular, 1.1-2.8 $\mathrm{mm}$ long, 1.4-2.4 $\mathrm{mm}$ wide, obtuse, with a mucronate tip 
0.1-0.4 mm long, keeled, the midrib conspicuous and thickened overall, glabrous and with minutely fringed margins. Sepals ovate, $2.7-4.8 \mathrm{~mm}$ long, $1.2-1.8 \mathrm{~mm}$ wide, acute, with a mucronate tip $0.15-0.4 \mathrm{~mm}$ long, the midrib inconspicuous, unthickened, glabrous and with minutely fringed margins. Corolla: tube broad-cylindrical, equal to or exceeding the sepals (Figure $4 \mathrm{f}, \mathrm{g}$ ), 3-6 mm long, 1.7-2.7 mm wide just below the lobes, glabrous outside, sparsely hairy inside over the upper third to half
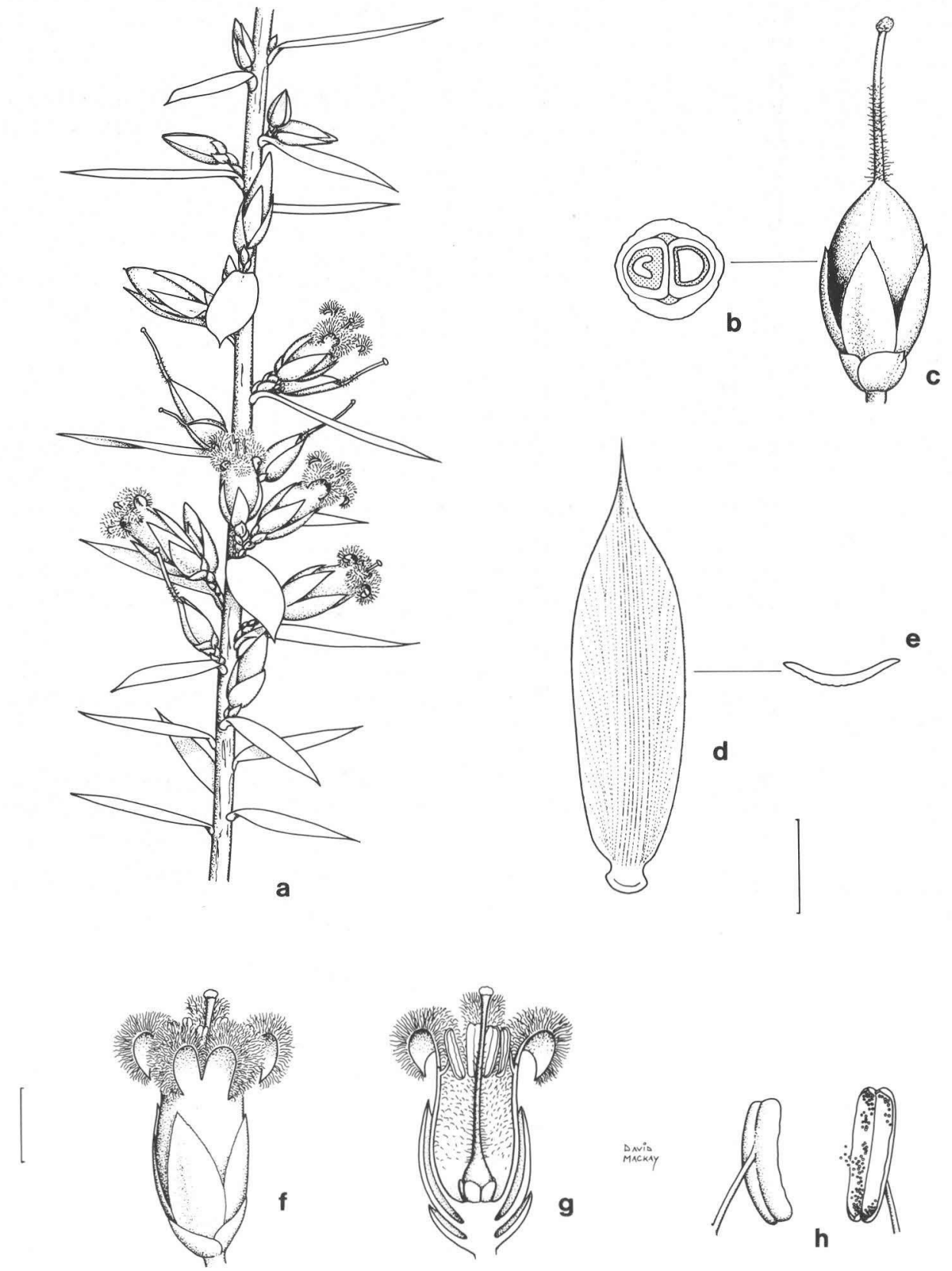

Figure 4. Flowering branch, leaf, flower and fruit structure of Leucopogon trichostylus J. Powell. a, flowering branch (Williams NSW 250764, scale bar $=6 \mathrm{~mm}$ ); $\mathbf{b}, \mathbf{c}$, young fruit transverse section and structure; $d, e$, leaf detail and transverse section; $f, g$, flower and flower section (all McKay 1068, scale bar = $2.5 \mathrm{~mm}) ; \mathbf{h}$, anther detail $($ McKay 1068, scale bar $=1 \mathrm{~mm})$. 
or sometimes overall; lobes erect at the base, speading to recurved above, $2.6-4.6 \mathrm{~mm}$ long, 0.8-1.2 mm wide, narrowly acute, externally glabrous, or with a few hairs near the apex, internally densely bearded overall with ornamented and often twisted hairs (Figure $5 \mathrm{~h}$ ), but with $0.1-0.5 \mathrm{~mm}$ glabrous at the tip, the beard long overall; lobes usually shorter than the tube. Anthers rectilinear (Figures $4 \mathrm{~h}, 6 \mathrm{a}$ ), 1.1-1.5 mm long, obvious between the erect lobe bases; filaments terete, 0.6-2 mm long, attached near the apex and fused down towards the midpoint, inserted at the base of the lobes. Ovary ovoid-deltoid (Figure 6f), $0.8-1.3 \mathrm{~mm}$ high, $0.7-1 \mathrm{~mm}$ wide, acutely lobed or ridged, glabrous, 5-locular; style $3.3-7.7 \mathrm{~mm}$ long, just exserted, filiform and papillose immediately below the stigma (Figure 6j), thickening towards the base and hairy over the lower half, becoming densely so towards the base (Figure 6e, f); stigma $0.25-0.4 \mathrm{~mm}$ high, very distinctly lobed (Figure 6i); nectary annular, $0.5-0.7 \mathrm{~mm}$ high, glabrous, joined over lower half or third only and with irregularly lobed upper margin (Figure 6f). Fruit exceeding the sepals (Figure 4c), ovoid, 3.5-4.2 mm high, 2.2-2.7 mm wide, the apex rounded (the style base often persistent), angled, glabrous, thinly fleshy.

DeRIVATION OF EPITHET: From the Greek trichion, small hair, and stylos, pillar, referring to the hairy lower half of the style.

FLOWERING AND FRUITING PERIOD: Flowers recorded April to October (except July) with fruit recorded in October and December.

НАВітАт: Found most commonly in skeletal sandy soils on rocky outcrops or amongst rocks on the edges of gorges and very steep slopes within scrub patches or in open eucalypt woodlands of E. melliodora and E. retinens at altitudes of 240-450 m or more.

Distribution: Known from the North Coast and Northern Tablelands of New South Wales and from the Darling Downs, Moreton and Burnett districts of Queensland (Figure 3).

CONSERVATION STATUs: Conserved in a number of National Parks including Oxley Wild Rivers, Apsley Gorge, Guy Fawkes River and Cathedral Rocks; the species does not appear to be endangered.

NoтEs: This species is most closely related to Leucopogon fraseri DC. and is currently placed within Bentham's Section Pleuranthus, series Planifoliae (Bentham 1869). The two species differ in habit: $L$. trichostylus is an erect to spreading shrub up to $2 \mathrm{~m}$ high with many sparsely-leaved intertwining branches, while L. fraseri is a low or more or less prostrate shrub ascending to $20 \mathrm{~cm}$, with densely leaved branches. L. trichostylus has rather larger leaves with a narrow leaf apex (Figure 5a, b) and a longer petiolar area than $L$. fraseri. Both species have plate wax on the lower surfaces of the leaves (Figure $5 \mathrm{e}, \mathrm{f}, \mathrm{g}$ ). In flower structure the two species are very similar: both have rectilinear anthers (Figure 6a, d) that are attached to the filaments at or above the midpoint and styles that are pilose over the lower half or overall. They differ in the density of hairs at the base of the style (Figure $6 \mathrm{e}, \mathrm{f}, \mathrm{g}$ ) and in the ovary shape and nectary (Figure 6f, g). Both have large, clearly lobed stigmas (Figure 6h, i) and are papillose immediately below the stigma (Figure $6 \mathrm{j}, \mathrm{k}$ ). The pollen of both species is spherical, periporate and scabrate, differing only slightly in size (Figure $6 \mathrm{~b}, \mathrm{c}$ ). The corolla hairs are single-celled, often twisted and strongly ornamented, the tubercles being denser and more variable in size in L. fraseri than in L. trichostylus (Figure $5 h, i)$.

Specimens of this taxon in New South Wales have been placed previously under L. sp. aff. fraseri and L. sp. aff. biflorus and in the Queensland Herbarium under L. biflorus or sometimes L. cuspidatus. L. trichostylus resembles L. biflorus somewhat in habit, but differs from it in androecial and gynoecial characters, the anthers in 

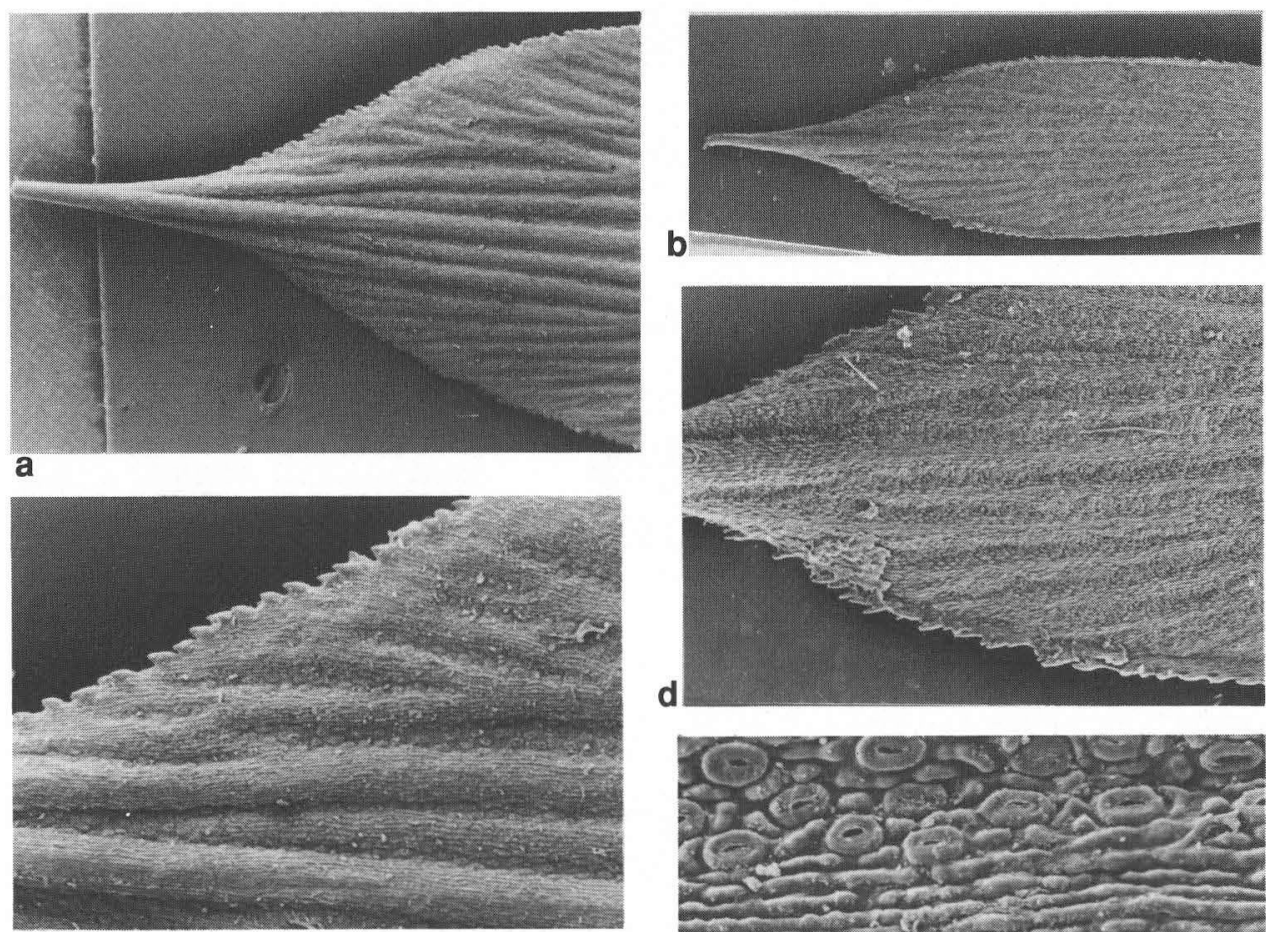

C
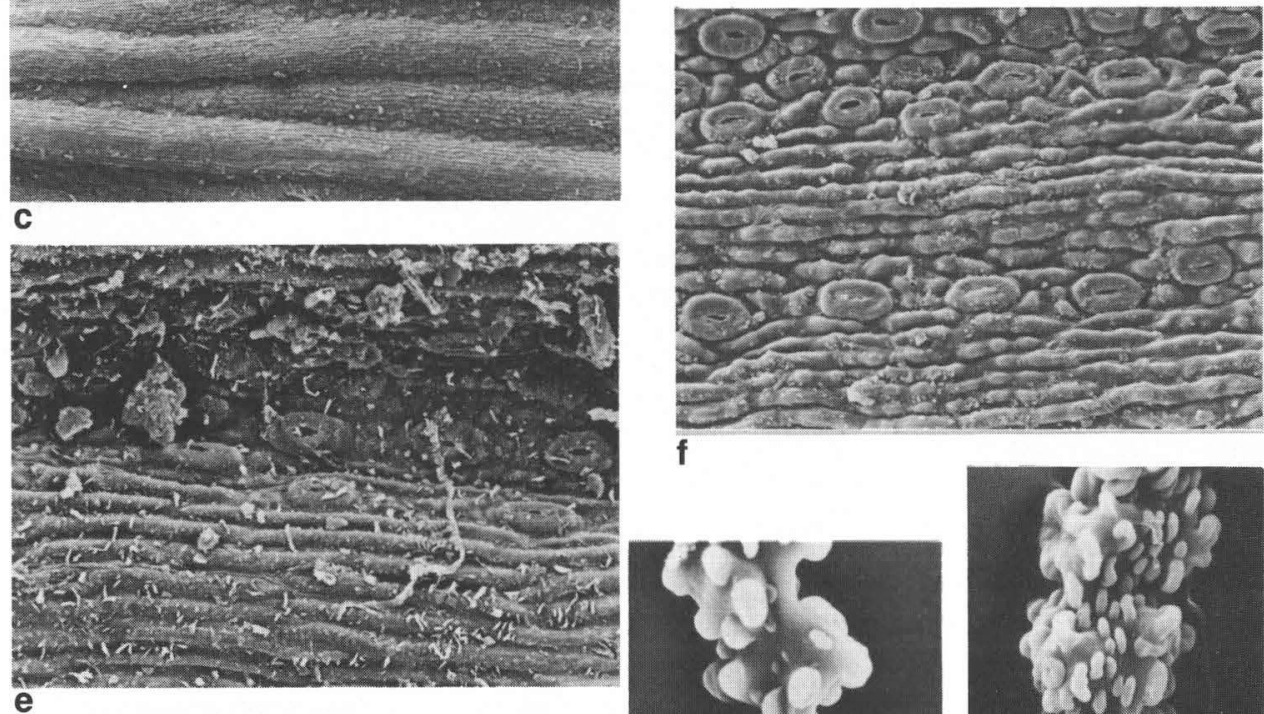
f
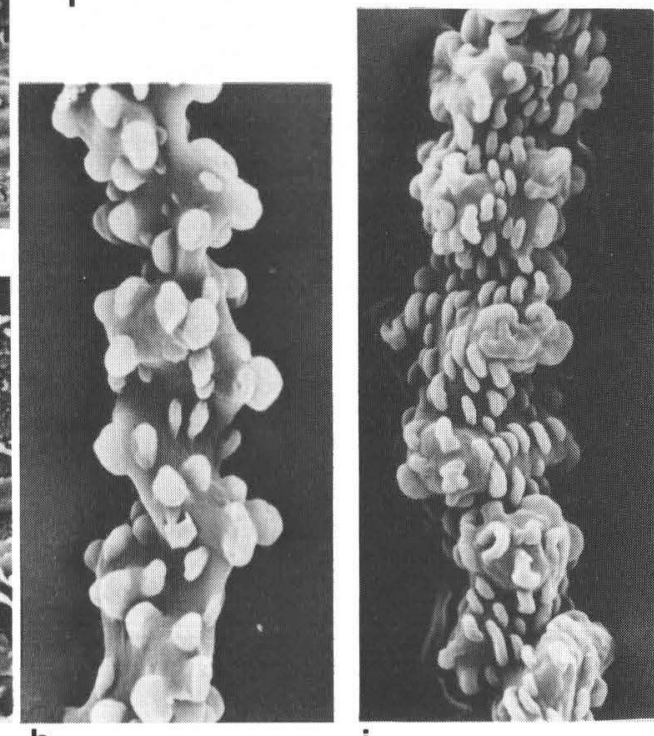
g

h

i

Figure 5. Scanning electron micrographs of L. trichostylus $(\mathbf{a}, \mathbf{c}, \mathbf{e}, \mathbf{g}, \mathbf{h})$ and $L$. fraseri $(\mathbf{b}, \mathbf{d}, \mathbf{f}, \mathbf{i})$. a, $\mathbf{b}$, leaf apex (x 17); c,d, leaf margin near apex (x 44); e,f, abaxial surface of leaf (x 275); $g$, leaf wax, abaxial surface (x 1650); h,i, corolla hairs (x 1100). 

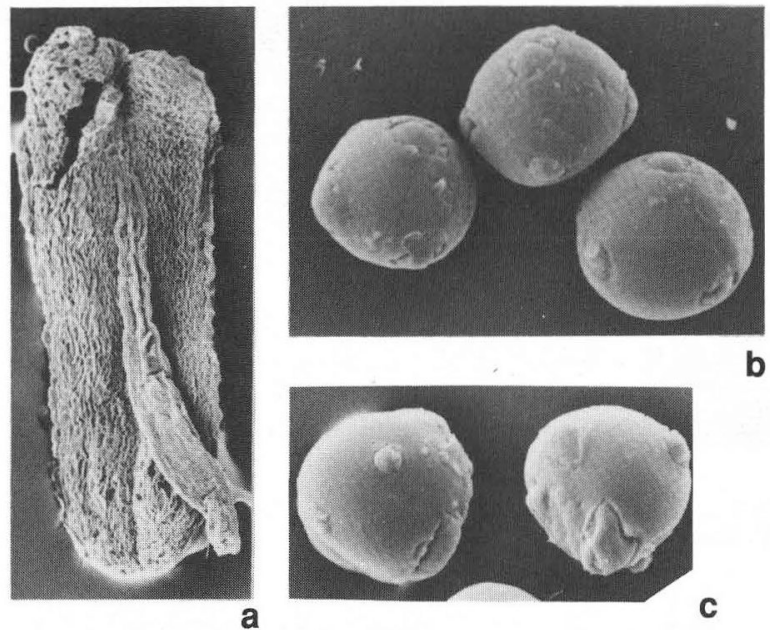

b

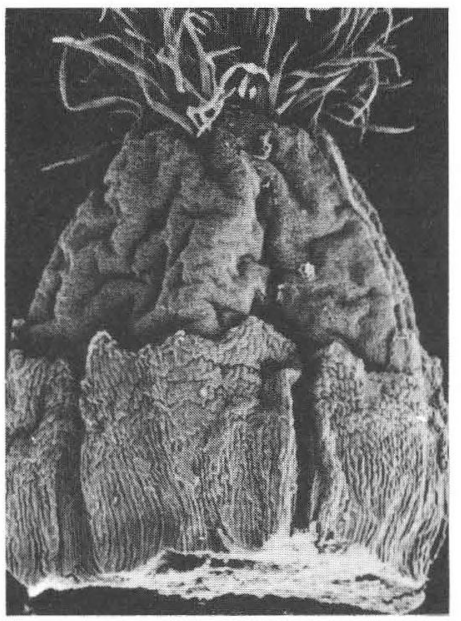

f

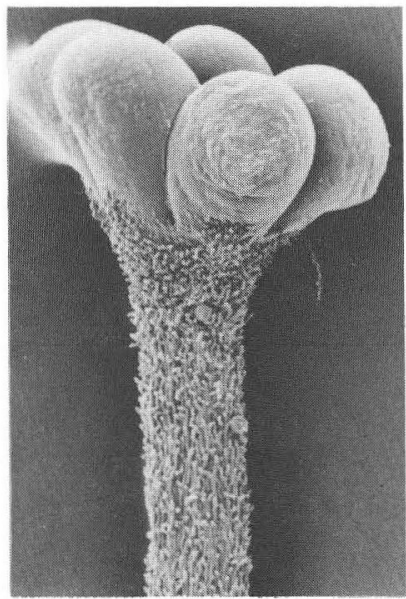

i

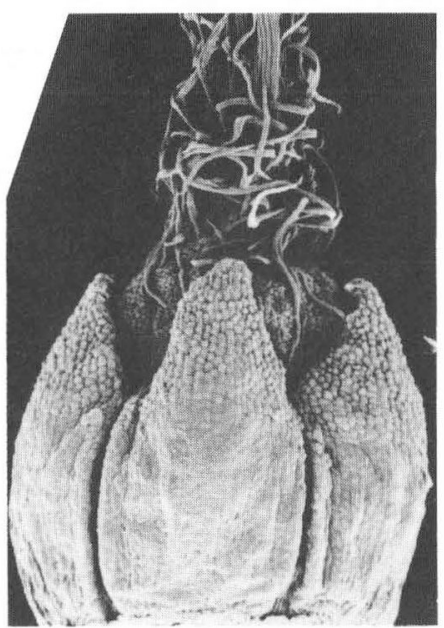

g

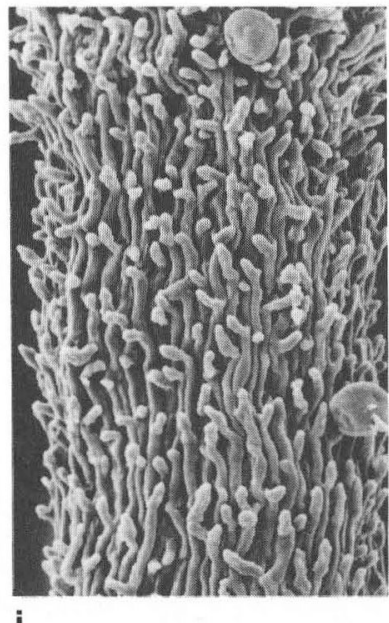

j

k
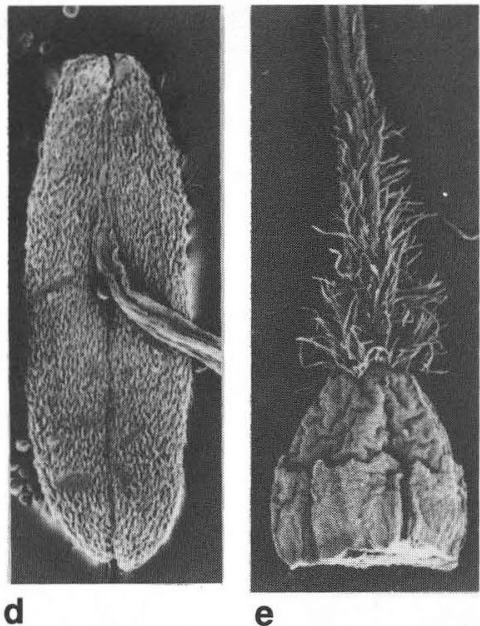

e

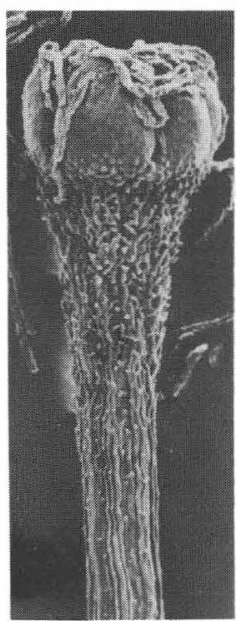

h

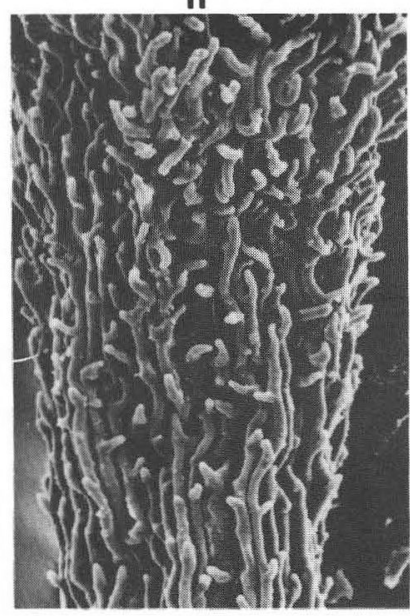

Figure 6. Scanning electron micrographs of L. trichostylus $(\mathbf{a}, \mathbf{b}, \mathbf{e}, \mathbf{f}, \mathbf{i}, \mathbf{j})$ and $L$. fraseri $(\mathbf{c}, \mathbf{d}, \mathbf{g}, \mathbf{h}, \mathbf{k})$. a,d, anther and filament ( $x 55)$; b,c, pollen ( $x 500$ ); e, lower part of style, ovary and nectary ( $x$ 28); f,g, lower style hairs, detail of nectary (x 66); $\mathbf{h}, \mathbf{i}$, stigma and upper style (x 66); j,k, surface papillae of upper style (x 220). 
L. biflorus being ovate, the style glabrous, the stigma small and truncate and the nectary acuminately lobed (Figure $10 \mathrm{a}, \mathrm{b}, \mathrm{c}$ ). Additionally the corolla hairs of L. biflorus are more densely tuberculate (Figure 10d).

Specimens eXamined: New South Wales: North Coast: Green Gully, Binns 142, 24 May 1987 (NSW); Georges Creek, via Kempsey, Boorman, Jan 1907 (NSW 250762); Wollomombi-Kempsey road, c. 3 km W of Middle Creek, Mackay 1068, 3 Apr 1990 (NE). Northern Tablelands: Tia falls, Walcha District, Betche, Dec 1898 (NSW 250759); Williams, 10 Sep 1966 (NE 045175, NSW); Wollomombi Falls, Hayes - (NSW 250761), Williams, Jun 1960 (NE 049693, NSW); Metz Gorge near Armidale, McBarron 20303, 10 Sep 1971 (NSW); Tia Falls area, Apsley Gorge National Park, Powell 2969, 1 Sep 1987 (NSW, HO, NY); Checks Lookout area, Wollomombi Falls, Powell 2973, 2 Sep 1987 (NSW, CBG, K); Apsley Falls, E. of Walcha, Williams, 10 Sep 1966 (NE 045097, NSW); near Chaelundi Falls, Guy Fawkes River National Park, Williams, Sep 1982 (NE 048714). QueENSLAND: Moreton: Ivory Rock, S of Ipswich, Blake 21882, 16 June 1962 (BRI); Ipswich, Hall 15, - (BRI). Burnett: Goodger road, Michael 3053, 21 Oct 1947 (BRI). Darling Downs: Highfields, 8 miles [13 km] N of Toowoomba, Salasoo 5491, 30 Dec 1974 (NSW); SE of Toowomba, Thompson, 29 Aug 1966 (BRI 073157).

\section{Leucopogon fletcheri Maiden \& Betche}

This species was named and described from specimens collected by J.J. Fletcher near Springwood in the Blue Mountains of New South Wales. Maiden \& Betche (1897) noted that their new species was allied to L. juniperinus R. Br. and that specimens from Tumut (Southern Tablelands) appeared to form a connecting link between the two species. Study of these specimens and more recent collections indicate that a distinct taxon exists within this group. It is more closely allied to L. fletcheri than to L. juniperinus and is considered to be a subspecies of the former.

The two subspecies are similar in habit, in leaf shape and structure and in flower structure, but differ to some extent in branchlet hairiness, in leaf size and flower size, the number of flowers usually borne in each inflorescence, and in fruit size. Table 1 summarizes the main features and Figures 7 and 8 compare the leaf surface features, corolla hairs, pollen and androecial and gynoecial attributes of the two taxa. As the ranges of measurements overlap and the qualitative attributes do not differ significantly the two taxa are considered to be subspecies rather than distinct species.

The taxa are allopatric (Figure 9). L. fletcheri subsp. fletcheri is known from a few collections only, from Springwood, Blaxlands Ridge and Kurrajong in the lower Blue Mountains and from the Annangrove district, near Rouse Hill. It flowers between August and October, with fruit recorded also in October. It has not been collected in recent years and must be considered as rare and endangered, if not already extinct. L. fletcheri subsp. brevisepalus is more widespread; it is known from Mt Werong in the Central Tablelands and recorded widely in the Southern Tablelands of New South Wales at $600-1650 \mathrm{~m}$ altitude, and in various parts of Victoria. It flowers between September and November, with fruit recorded December to February. 
Table 1. Comparison of attributes of taxa within L. fletcheri

\section{Attribute}

Plant height (m)

Branchlet indumentum

Leaf-blade length ( $\mathrm{mm}$ )

Leaf-blade width $(\mathrm{mm})$

Leaf length: width ratio

No. flowers per inflorescence

Sepal length ( $\mathrm{mm})$

Corolla-tube length $(\mathrm{mm})$

Corolla-lobe length $(\mathrm{mm})$

Anther length ( $\mathrm{mm}$ )

Filament length $(\mathrm{mm})$

Style length $(\mathrm{mm})$

Fruit shape

Fruit length (mm) subsp. fletcheri

$1.5-1.8$

hispidulous or scabridulous

$4.5-8.0$

$1.4-1.9$

$2.5-4.5: 1$

1 + rudiment

$3.4-4.6$

$3.5-4.8$

$2.8-3.8$

$0.9-1.1$

$0.55-0.7$

$5.4-7.9$

obovate

$4.7-5.0$ subsp. brevisepalus

$0.3-1.0$

hispid or pilose

$3.7-7.8$

$1.7-3.1$

$1.9-4.4: 1$

1-3 + rudiment

$2.1-3.5$

$2.6-3.9$

$2.4-3.1$

$1.0-1.5$

$0.6-0.9$

$3.9-5.5$

elliptical

$3.0-3.4$

Leucopogon fletcheri Maiden $\mathcal{E}$ Betche subsp. brevisepalus J. Powell, subsp. nov.

$\mathrm{Ab}$ subspecie fletcheri inflorescentiis 1-3-floribus, sepalis corollisque stylisque brevioribus sed antheris et filamentis aliquantum longioribus, staturis inferioribus, foliis latioribus, ramulis pilosis vel hispidulis, differt.

TyPE: New South Wales: Southern Tablelands: Tinderry Mountains, T.G. Hartley 13386, 17 Oct 1971 (holo NSW, iso CANB).

An erect to spreading shrub, 30-100 cm high. Stems grey or grey-brown, glabrous; branchlets red-brown, hispidulous to pilose. Leaves sub-erect to spreading (Figure 10a), oblong or \pm ovate or elliptic, 3.7-7.7 mm long, 1.4-3.1 mm wide (length:width = 1.9-4.1:1) ; apex acute or acuminate with an aristate tip 0.4-1.1 mm long (Figures $7 \mathrm{c}$, $\mathrm{g}$, 10d); base truncate; lamina convex adaxially (Figure 10e), discolorous, the lower surface paler, glabrous or pilose (Figure $7 \mathrm{f}, \mathrm{j}, \mathrm{k}$ ); venation inconspicuous above, shallowly striate-grooved below, with three central parallel veins prominent towards the apex and others sub-parallel; margins usually recurved, denticulate-serrulate or pilose (Figure 7d, h) or rarely entire; petiole ill-defined, $0.3-0.5 \mathrm{~mm}$ long, glabrous or pilose. Young seasonal growth leaves shorter ( $2-4 \mathrm{~mm}$ long), usually obovate with distinctly hyaline, pilose margins. Flowers pendent (Figure 10a), white, cream or pinktinged, axillary, extending along the short branchlets, 1-3 together plus a bract-like rudiment; peduncles recurved, 0.8-1.5 mm long. Bracts scarious, ovate, striate-veined, 0.7-1.0 mm long, $1.0-1.2 \mathrm{~mm}$ wide, obtuse and mucronulate to $0.1-0.2 \mathrm{~mm}$, glabrous or with hairs on the midrib or near apex and the margins minutely fringed. Bracteoles sub-orbicular, 1.1-1.6 mm long, 1.6-2 mm wide, obtuse with mucro 0.2-0.3 mm long, glabrous or with scattered hairs along the midrib or near the apex, or puberulent to pubescent overall, the margins glabrous or finely fringed near the apex. Sepals ovate, 


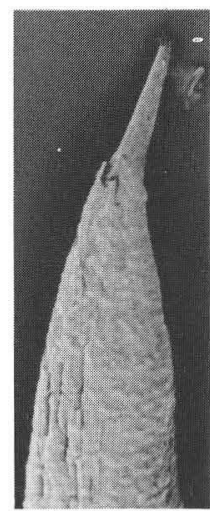

a

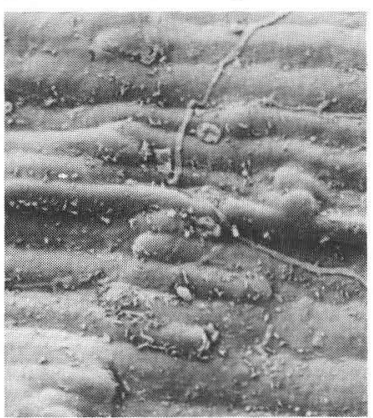

e

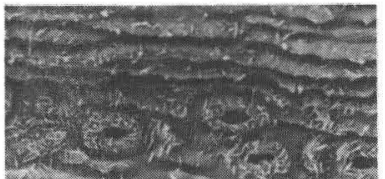

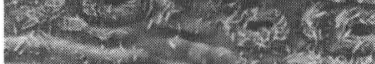

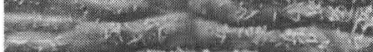

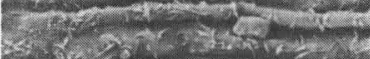

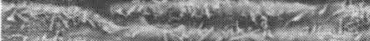

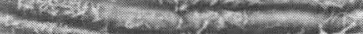

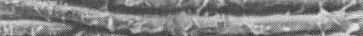

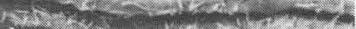
i

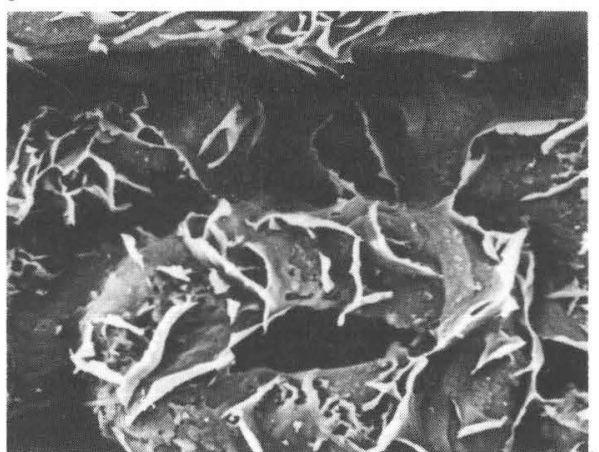

\section{f}

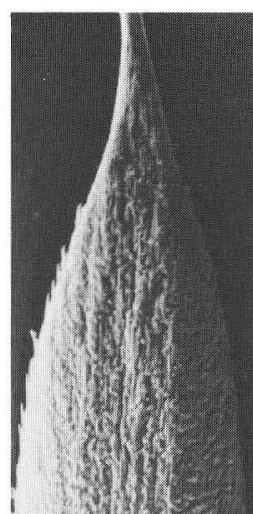

C
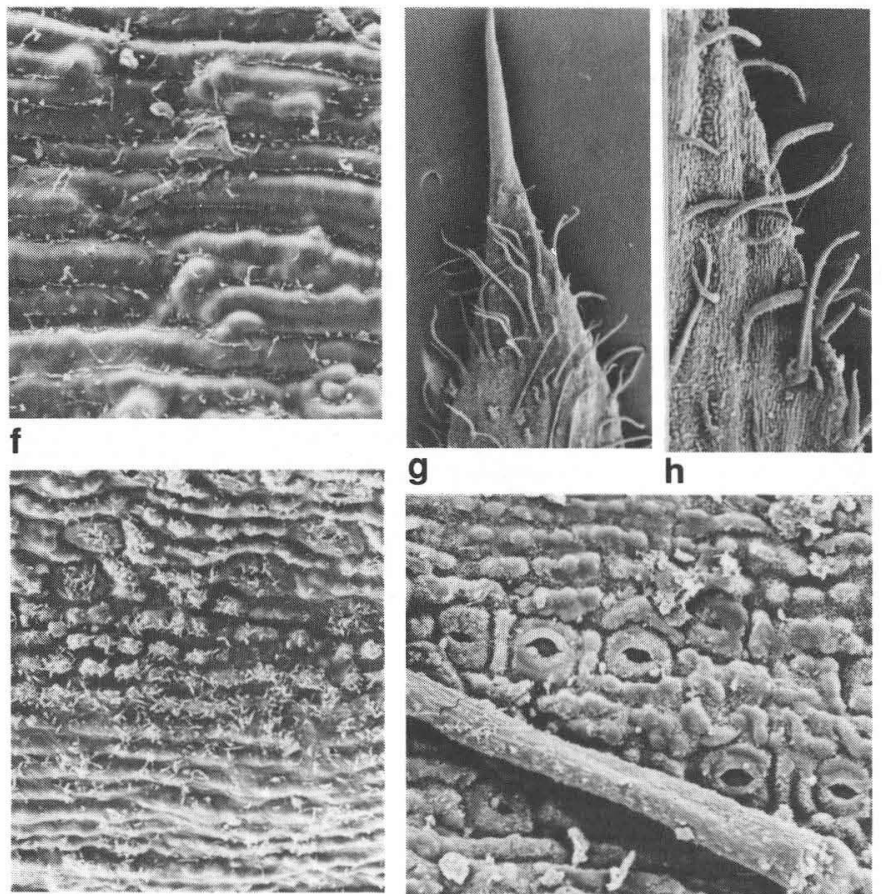

h

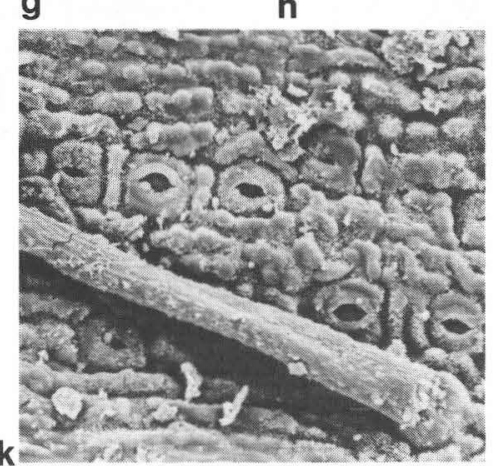

Figure 7. Scanning electron micrographs of L. fletcheri subsp. fletcheri $(\mathbf{a}, \mathbf{b}, \mathbf{e}, \mathbf{i}, \mathbf{l})$ and subsp. brevisepalus glabrous variant $(\mathbf{c}, \mathbf{d}, \mathbf{f}, \mathbf{j})$ and pilose variant $(\mathrm{g}, \mathbf{h}, \mathbf{k}, \mathbf{m}) . \mathbf{a}, \mathbf{c}, \mathbf{g}$, leaf apex $(\mathbf{x} 17) ; \mathbf{b}, \mathbf{d}, \mathbf{h}$, leaf margin near apex (x 44); $\mathbf{e}, \mathbf{f}$, adaxial leaf surface ( 275$) ; \mathbf{i}, \mathbf{j}, \mathbf{k}$, abaxial surface of leaf ( 275$)$; $\mathrm{l}, \mathrm{m}$, leaf wax, abaxial surface, $(1 \times 1650, \mathrm{~m} \times 1100)$. 


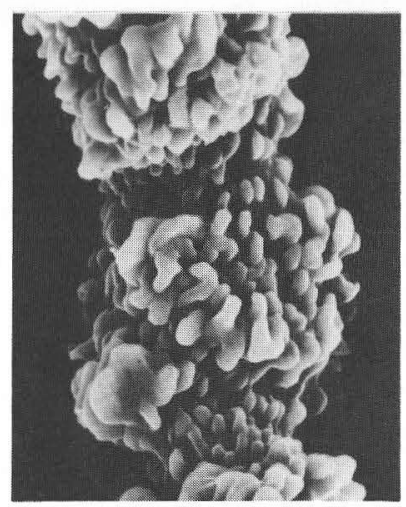

a

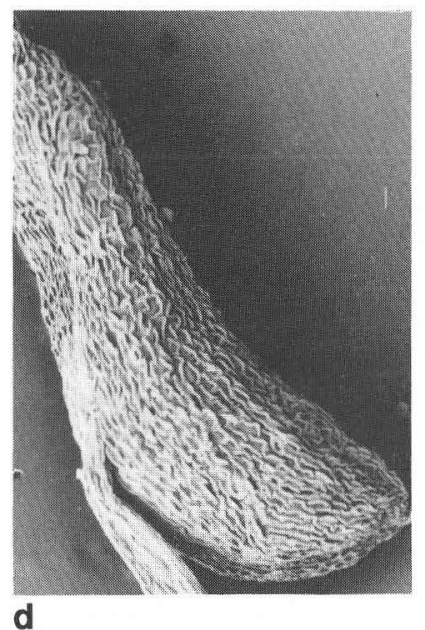

d

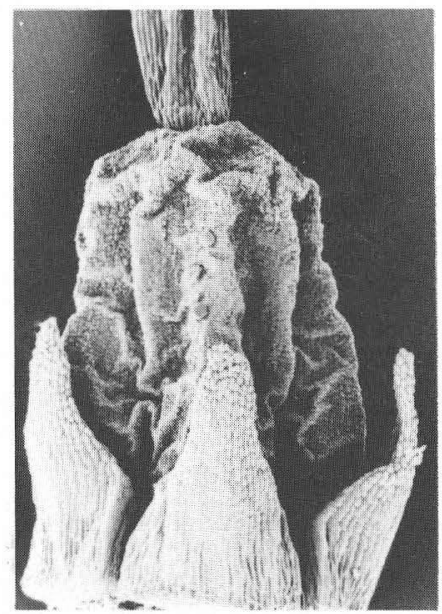

i

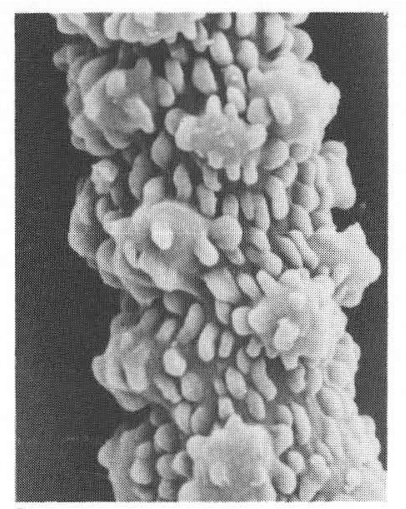

b

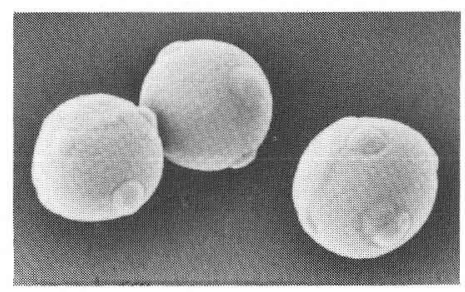

e

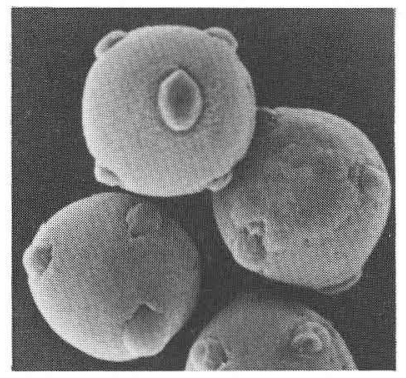

g

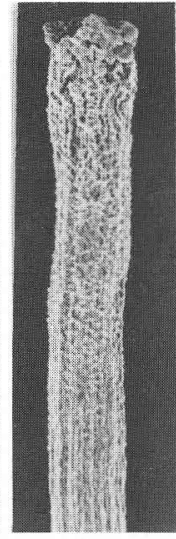

j

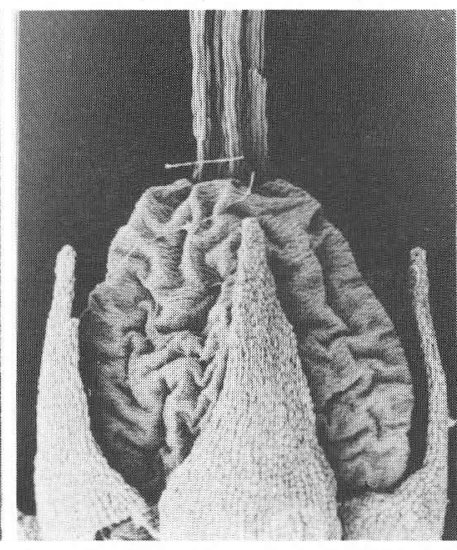

k

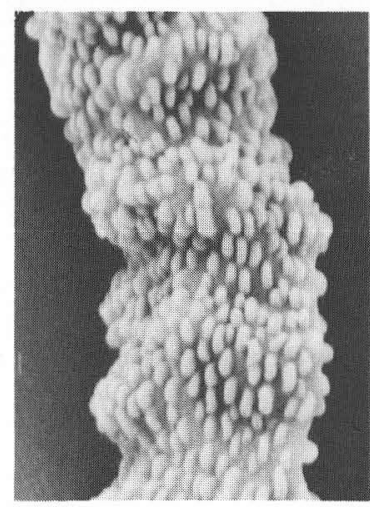

C

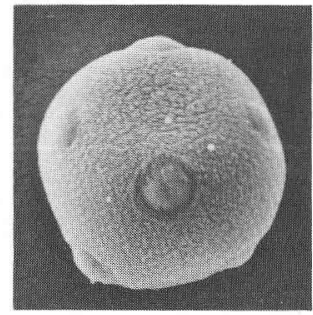

f

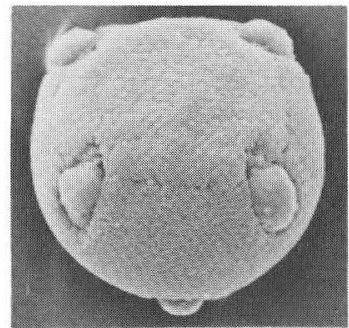

h

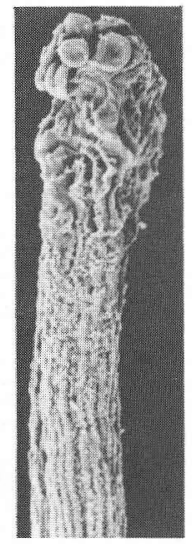

I

Figure 8. Scanning electron micrographs of $L$. fletcheri subsp. fletcheri $(\mathbf{c}, \mathbf{g}, \mathbf{h}, \mathbf{k}, \mathbf{l})$ and subsp. brevisepalus glabrous variant $(\mathbf{a}, \mathbf{d}, \mathbf{e}, \mathbf{f}, \mathbf{i}, \mathbf{j})$ and pilose variant $(\mathbf{b})$. a,b,c, corolla hairs (x 1100); d, anther (x 60); e,g, pollen (x 850); f,h, pollen ( $x$ 850); i, k, style base, ovary and nectary, (i x 6, k $x$ 55); j,l, upper style and stigma, (j x 66, 1 x 110). 
2.6-3.5 mm long, 1.1-1.5 mm wide, acute or broadly acute, apiculate, glabrous or pilose near the apex, and with finely fringed margins. Corolla: tube equal to or longer than the sepals, narrow- to broad-cylindrical (Figure 10f, g), 2.6-4.0 mm long, 1.0-3.0 $\mathrm{mm}$ wide, externally glabrous, internally with scattered hairs over the upper third; lobes shorter than the tube or sometimes equal, the lower half erect, the upper half reflexed, 2.4-3.2 mm long, 0.7-1.3 mm wide, acute, externally glabrous or sparsely pubescent near the apex, internally the upper third pubescent, the lower two-thirds sparsely pubescent or pilose. Anthers dark maroon, obvious between the erect lobe bases, ovate, $1.0-1.2 \mathrm{~mm}$ long (Figures $8 \mathrm{~d}, 10 \mathrm{~h}$ ); filaments $0.5-0.8 \mathrm{~mm}$ long, attached to the anther below the mid-point. Ovary ovoid to ellipsoid (Figure 8i), 0.9-1.1 mm long, 0.6-0.7 mm wide, slightly 5-ridged, glabrous, 5-locular; style filiform, 2.8-5.3 $\mathrm{mm}$ long and just exserted from the corolla tube, glabrous; stigma truncate (Figure 8j); nectary annular, $0.5-0.8 \mathrm{~mm}$ high, glabrous with an acuminately lobed upper margin (Figure 8i). Fruit just exceeding the sepals (Figure 10b, c), ellipsoid or obovate, 3-3.3 $\mathrm{mm}$ high, 1.5-1.9 $\mathrm{mm}$ wide, the apex rounded acute, the surface finely ribbed, glabrous.

DeRIVATION OF EPITHET: From the Latin brevis, short, and sepalus, sepal, referring to the shorter sepals of the new subspecies.

FLOWERING \& FRUITING PERIOD: Flowering between September and November, with fruit recorded December to February.

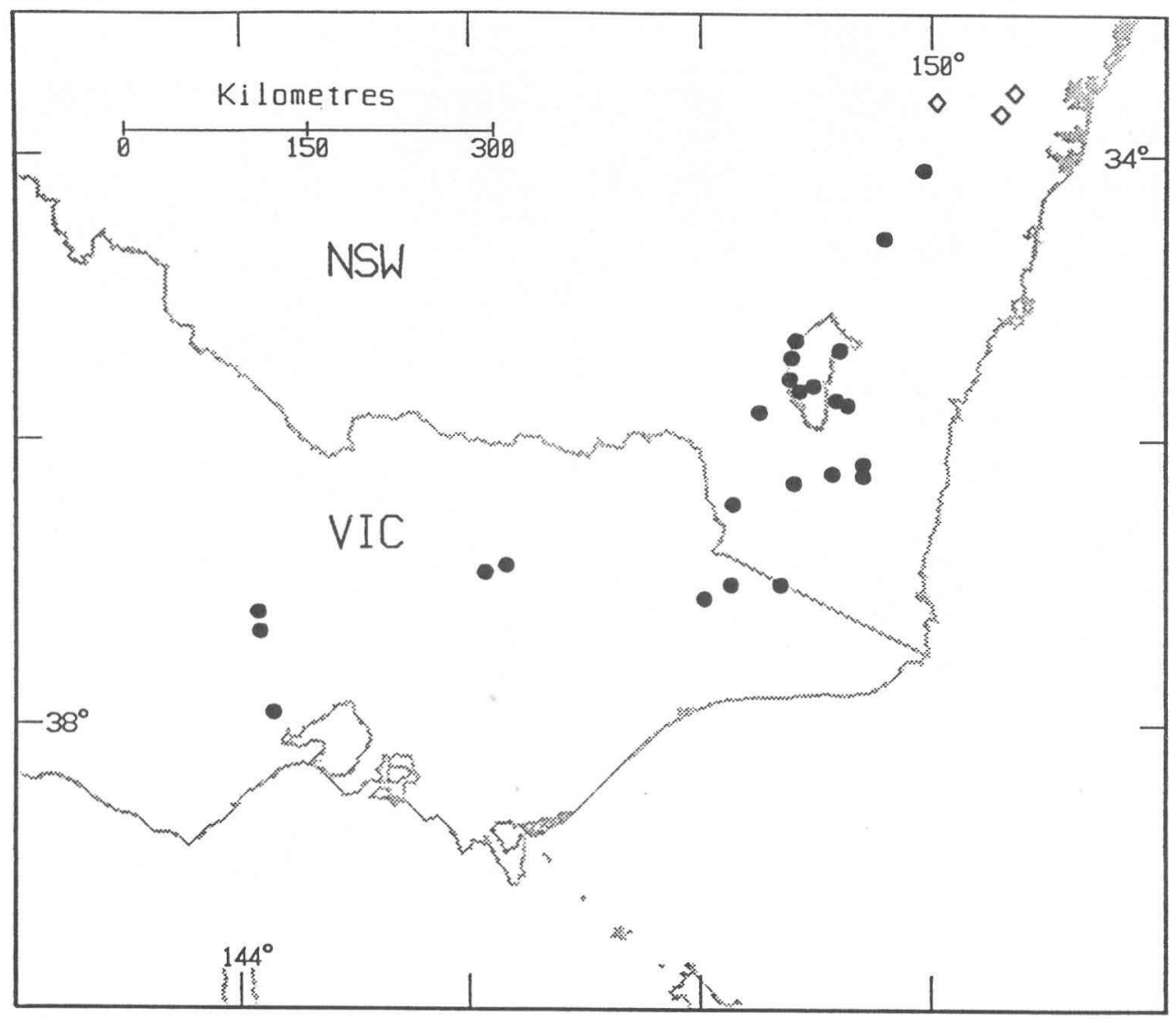

Figure 9. Distribution of L. fletcheri subsp. fletcheri $(\diamond)$ and subsp. brevisepalus $(\bullet)$. 
НавітAт: Found mainly in open eucalypt forests and woodlands at $600-1680 \mathrm{~m}$ altitude, on stony and sandy yellow-brown or orange-brown soils on various substrates; often locally common.

Distribution: Known from Mt Werong in the Central Tablelands and recorded widely in the Southern Tablelands of New South Wales; also from a number of localities in Victoria (Figure 9).

CONSERVATION STATUS: A relatively widespread taxon not considered endangered.

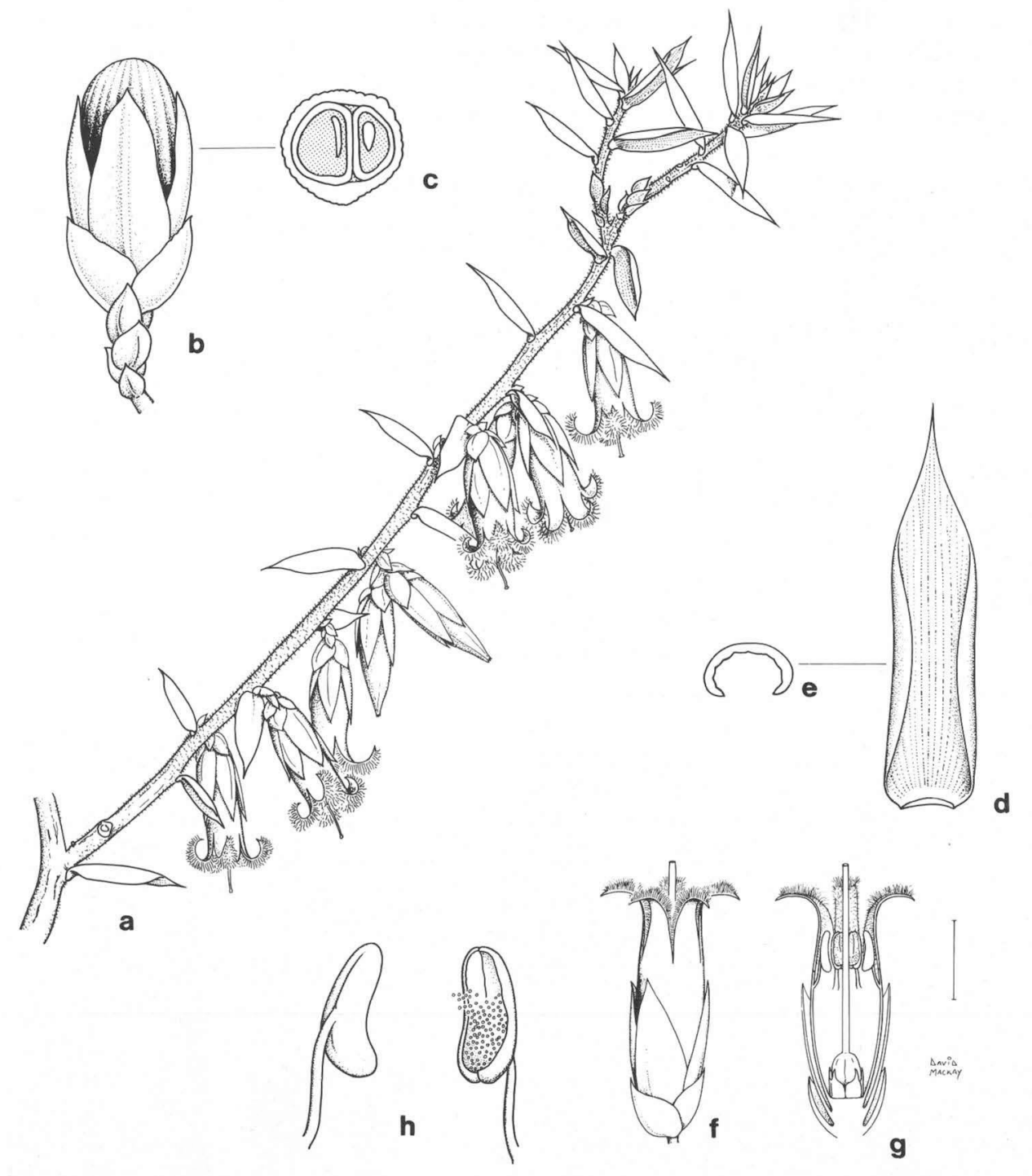

Figure 10. Flowering branch, leaf, flower and fruit structure of Leucopogon fletcheri F. Muell. subsp. brevisepalus J. Powell. a, flowering branch (Pullen 2346, scale bar $=5 \mathrm{~mm}$ ); b,c, fruit structure (Powell $298 \&$ \& McGrath, scale bar $=2 \mathrm{~mm}$ ); d,e, detail of leaf and transverse section (Pullen 2346, scale bar $=2 \mathrm{~mm}$ ); $\mathbf{f}, \mathbf{g}$, flower and flower section (Hartley 13386, scale bar $=2 \mathrm{~mm}$ ); h, anther detail (Hartley 13386, scale bar $=1 \mathrm{~mm}$ ). 
Notes: Within subsp. brevisepalus both glabrous- and pilose-leaved specimens have been found, the latter having also puberulent to pubescent sepal apices. These are not accorded taxonomic rank as no other differences between them have been found. Both variants have been recorded at the same locality and occur throughout the subspecies' geographical distribution range.

Specimens of L. fletcheri subsp. brevisepalus from Victoria have been called L. biflorus, on the basis of the pendent 2-flowered inflorescence. L. biflorus differs from L. fletcheri in having rather longer leaves with a longer aristate tip and the lamina flat or only very slightly convex (or concave) adaxially, and often concolorous. In flower structure, particularly androecial and gynoecial attributes, the two species are very similar (cf. Figures 8, 11). L. fletcheri is more closely related to L. biflorus than to L. juniperinus (Figure $11 \mathrm{e}-\mathrm{h}$ ), previously suggested to be the closest relative (Maiden \& Betche 1897). L. juniperinus is more closely related to $L$. fraseri and L. trichostylus in having rectilinear anthers and the stigma well developed and clearly lobed (cf. Figures 5, 6

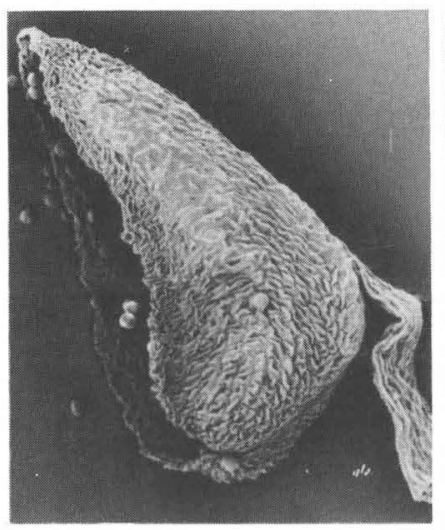

a

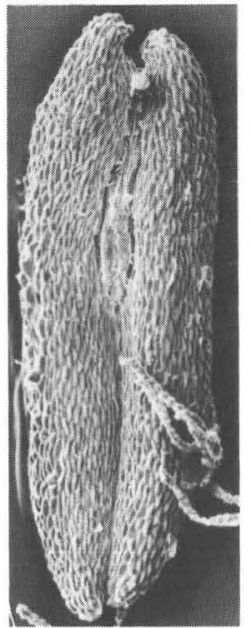

e

f

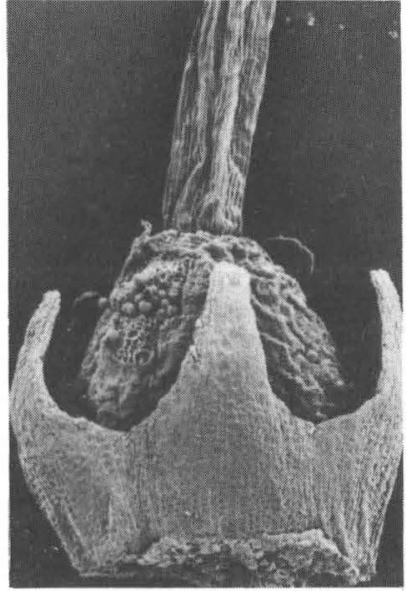

b

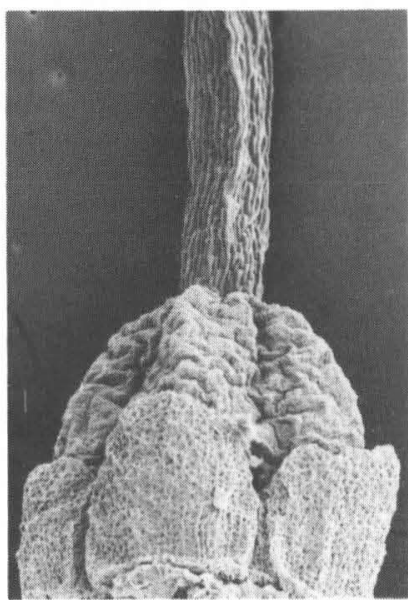

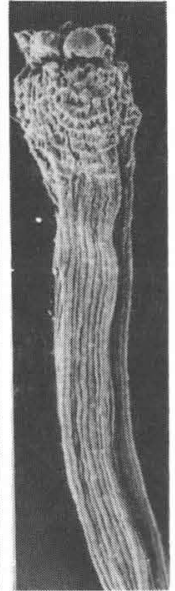

C

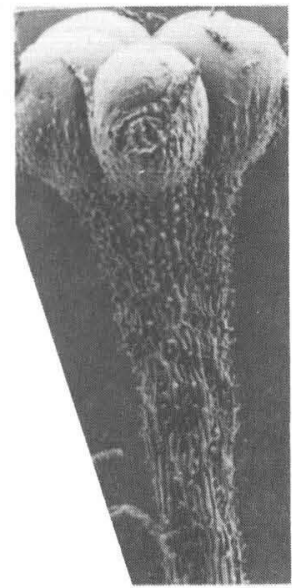

g

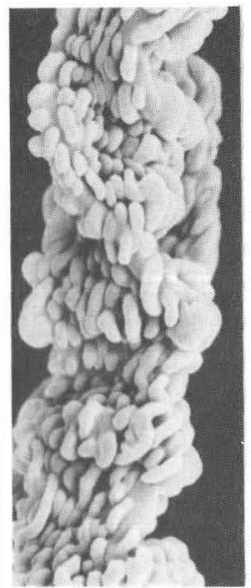

d

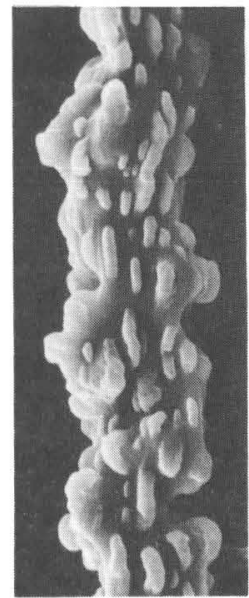

h

Figure 11. Scanning electron micrographs of L. biflorus (a-d) and L. juniperinus (e-h). a,e, anther (x 60); b,f, style base, ovary and nectary, (b x 40, f x 66); c,g, upper style and stigma (x 66); d,h, corolla hairs ( $x$ 1100). 
and Figure 11). All species are currently included in Section Pleuranthus series Planifoliae of Bentham (1869).

\section{Leucopogon fletcheri subsp. brevisepalus}

Selected SPecimens examined: New South Wales: Central Tablelands: Mt Werong, Cambage, Oct 1909 (NSW 259428). Southern Tablelands: Yarrangobilly Caves, Betche, Feb 1897 (NSW 259427); 1.7 km direct NNW of Kybean Trig, 100 m E of Kybean East Fire Trail, Briggs 2090, 1 July 1987 (CANB, NSW, MEL); Slopes of Mt Jerrabombera, A.C.T., Burgess B275 (part), 14 Sep 1973 (CANB, NSW); $2.7 \mathrm{~km}$ from turnoff Dalton-Rugby Road at Bevendale, towards Crookwell, Canning 6433, 26 Sep 1987 (CBG, NSW); Bendora Hut, $5 \mathrm{ml}$ [8 km] SW of Bulls Head Camp, Brindabella Range, A.C.T., Constable, 29 Apr 1958 (NSW 259431); Bolaro-Canberra road near junction of Shanahans Mountain trail, Corrick 7002, 21 Oct 1980 (MEL, NSW); Top of Mt Coree, A.C.T., Gray 4989, 1 Feb 1961 (CANB, NSW); Foot of Black Mountain, A.C.T., Hoogland 8564, 13 Sep 1962 (CANB, NSW); Cowra Creek, Cooma, Moore, Oct 1899 (NSW 259426); Tumut, Moreland, Dec 1947 (NSW 259425); Cooma North Woodland, Parris 5, 16 Oct 1974 (NSW); $19 \mathrm{~km} \mathrm{~N}$ of Botanic Garden hut near Mt Gingera, A.C.T., Powell 292 \& McGrath, 4 Nov 1975 (NSW); Head of the Orroral Valley along track to Cotter Gap, A.C.T., Pullen 2328, 4 Nov 1960 (CANB, NSW); Primrose Valley road, ca. $20 \mathrm{mls}$ [32 km] S of Bungendore, Pullen 3865, 9 Oct 1963 (CANB, NSW). South West Slopes: Burrinjuck, Boorman, Feb 1911 (NSW 259429). Victoria: 16.2 km NW of Omeo on road to Anglers Rest, Albrecht 2879, 14 Oct 1986 (MEL, NSW); Mt Margaret track, Macalister Valley, Aston, 24 Oct 1972 (MEL 75715); Little River Falls, Bonang-Gelantipy Road, East Gippsland, Beauglehole 33803 \& Rogers, - (NSW, MEL); Mitta Mitta, Clinton, Nov 1918 (NSW 259430); Mt Bogong slopes, Hill, 1959 (NSW 259432); Whitfield road, $22 \mathrm{mls}$ [35 km] from Mansefield, Muir 1669, 31 Oct 1960 (MEL, NSW).

\section{Leucopogon fletcheri subsp. fletcheri}

SPECIMENS EXAMINED: Central Tablelands: Annangrove district [near Rouse Hill], Blaxell, 22 Sep 1961 (NSW 259435); 2.8 km NE of Blaxlands Ridge school, Coveny 12129 et al., 28 Aug 1985 (NSW, CBG); Springwood, Cross, 18 Aug 1934 (NSW 259436), Fletcher, Oct 1887 (NSW 259433); Blaxlands Ridge, near Kurrajong, Hungerford, - (NSW 259434).

\section{Acknowledgements}

We should like to thank John Williams for helpful discussions and for organizing the loan of University of New England herbarium material. We are grateful to Peter Wilson for checking the Latin, Tony Martin for assistance with the scanning electron micrographs, Barbara Wiecek for printing the photographs, and David Mackay for his botanical plates. We acknowledge also funding assistance for part of this work from the Australian Biological Resources Study.

\section{References}

Bentham, G. (1869) Flora Australiensis, vol. 4 (L. Reeve \& Co.: London).

Briggs, J.D. \& Leigh, J.H. (1988) Rare or Threatened Australian Plants. Australian National Parks \& Wildlife Service Special Publication no. 14.

Jacobs, S.W.L. \& Pickard, J. (1981) Plants of New South Wales. A census of the cycads, conifers and angiosperms. (Royal Botanic Gardens: Sydney).

Maiden, J.H. \& Betche, E. (1897) Descriptions of three new species of Australian plants. Proc. Linn. Soc. New South Wales 22: 150-152. 